\title{
Long-term trends of water chemistry in mountain streams in Sweden - slow recovery from acidification
}

\author{
H. Borg and M. Sundbom \\ Department of Applied Environmental Science (ITM) Stockholm University 10691 Stockholm, Sweden
}

Correspondence to: H. Borg (hans.borg@itm.su.se)

Received: 28 June 2013 - Published in Biogeosciences Discuss.: 6 August 2013

Revised: 3 December 2013 - Accepted: 4 December 2013 - Published: 10 January 2014

\begin{abstract}
The water chemistry of streams and precipitation in the province of Jämtland, northern Sweden has been monitored since the 1980 s to study long-term trends, occurrence of acid episodes, and effects of liming. The acidity in precipitation increased in the 1970s, followed by a loss of acid neutralizing capacity (ANC) and low $\mathrm{pH}$ in the streams. Sulfur deposition began to decrease in the 1980s, until approximately 2000, after which the decrease levelled out. Stream water sulfate concentration followed the precipitation trend but decreased more slowly and since the late 1990s a subtle increase was observed. Sulfate concentrations in the snow typically have been higher than or equal to the stream sulfate levels. However, during the period of rapid deposition decrease and also since 2005 stream sulfate has sometimes exceeded snow sulfate, indicating desorption of stored soil sulfate, possibly because of climate-related changes in runoff routes through the soil profiles, following shorter periods of frost.
\end{abstract}

From 1982 to 2000, total organic carbon (TOC) increased by approximately $0.1 \mathrm{mg} \mathrm{L}^{-1} \mathrm{yr}^{-1}$. The mean trends in sulfate and TOC from approximately 1990 until today were generally opposite.

Acidic episodes with $\mathrm{pH} 4.0$ at flow peaks occurred frequently in the unlimed streams, despite relatively wellbuffered waters at baseflow. To evaluate the main causes for the loss of ANC during episodes, the changes in major ion concentrations during high flow episodes were evaluated. The most important factors contributing to ANC loss were dilution of base cations $\left(\mathrm{Na}^{+}, \mathrm{K}^{+}, \mathrm{Ca}^{2+}, \mathrm{Mg}^{2+}\right)$, enrichment of organic anions and enrichment of sulfate.

Wetland liming started in 1985 after which the earlier observed extreme peak values of iron, manganese and aluminium, did not reoccur. The studied area is remote from emission sources in Europe, but the critical load of acidity is still exceeded. The long-term recovery observed in the unlimed streams is thus slow, and severe acidic episodes still occur.

\section{Introduction}

Acidic deposition has caused a widespread deterioration in the water quality of lakes, water courses, and soils in large parts of Europe, primarily Scandinavia and UK, (Almer et al., 1974; Dickson, 1980; Henriksen, 1980; Wright et al., 1980), and North America, primarily in the NE USA (Hendrey et al., 1980), and Quebec and Ontario in Canada (Dillon et al., 1980; Dillon et al., 1984). After several decades of increasing acidic deposition during the 1900s, the trend generally changed during the 1980s as a result of several international agreements to reduce sulfur emissions (e.g. UNEP, 1972; CLRTAP, 1979, 1985; Environment '82 Committee, 1982). The decrease of sulfur deposition has contributed to a recovery from acidification, which is currently being observed in the affected surface waters in several countries (Stoddard et al., 1999; Wilander and Lundin, 2000; Wilander, 2001).

Sweden has been severely affected by acid rain because of the dominating igneous bedrock and relatively sparse occurrence of calcareous bedrock. Approximately 15000 of a total number of approximately 85000 lakes less than $1 \mathrm{~km}^{2}$ were considered to be affected by anthropogenic acidification in 1990 (Swedish Environmental Protection Agency, 1991). Even in relatively remote areas in northern Sweden, low $\mathrm{pH}$ values in the snowpack were beginning to occur in the 1970s-1980s, which resulted in acidic episodes in streams (Ahlström and Isaksson, 1990; Laudon and Bishop, 


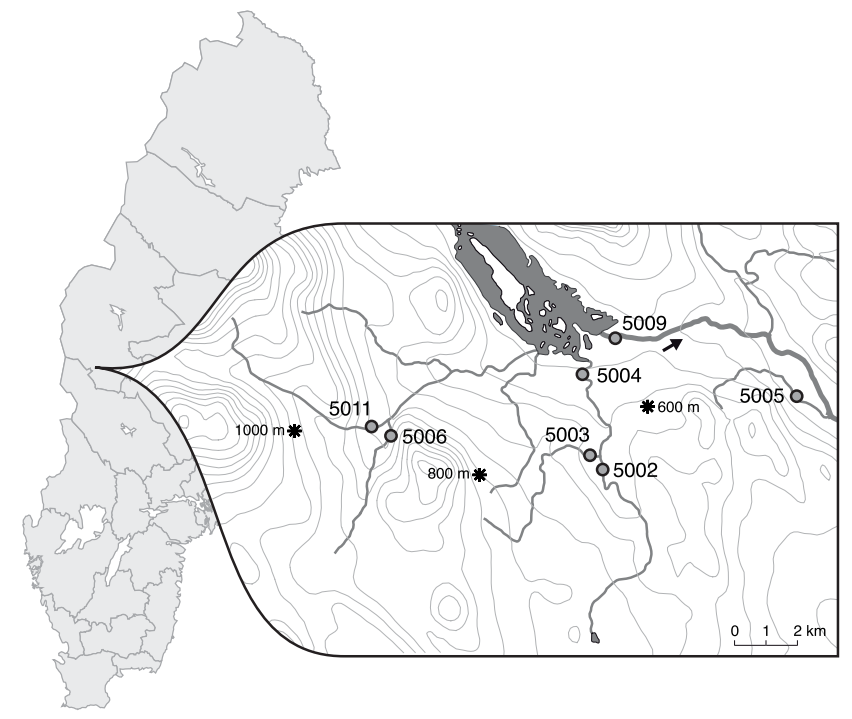

Fig. 1. Location and map of the study area with the stream-sampling stations and snowpack sites marked out. The snow sampling station at $400 \mathrm{~m}$ a.s.l. is outside the map about $40 \mathrm{~km}$ to the east.

1999; Edberg et al., 2001). Consequently, reproduction impairment and other negative effects on fish and benthic invertebrates have also been documented in numerous waters in northern Sweden (Ahlström et al., 1995; Andrén, 2009).

The streams in this investigation were monitored from the early 1980s, and the precipitation was monitored from 1975 to present. This study covers $30 \mathrm{yr}$, during a time period that has experienced dynamic changes in the deposition of acidifying substances over the area. The objectives of the present study were to follow the development of acidification and recovery, and the occurrence of acidic episodes. As a remediation, a large liming program began in the 1980s; therefore, another objective was to study the influence of the wetlands lime treatment on the mobility of metals, primarily $\mathrm{Fe}, \mathrm{Mn}$ and $\mathrm{Al}$.

\section{Methods}

\subsection{Study area}

The streams are located in the middle region of the Swedish mountain range, in the province of Jämtland, municipality of Härjedalen. These streams drain into the impoundment Lake Lofssjön and further downstream into the Lofsån River, which is a tributary of the Ljusnan River, one of the main rivers in N Sweden draining into the Bothnian Sea (Fig. 1). The catchments are in the size range of $10-50 \mathrm{~km}^{2}$ and are approximately $600-1000 \mathrm{~m}$ above sea level (a.s.l.), consisting of peatbogs and mires, coniferous forests, and tundra. The catchments also include a former lake basin from the last glaciation, which contains fine-grained sediments rich in $\mathrm{Fe}, \mathrm{Mn}$ and $\mathrm{Al}$.
As a remedy against the effects of acid precipitation, most of the streams were repeatedly treated with limestone (Table 1), which was applied by helicopter on the wetlands and primarily focused on sites with groundwater outflow. For a further description of the area and the lime treatments, see Andersson and Nyberg (1984), Borg (1986), Borg et al. (1995) and Nyberg et al. (1995). The river Häggingån was used as an unlimed reference stream. Due to a lime treatment of a nearby catchment, also draining into the Lake Lofssjön impoundment, we moved the sampling site a few kilometres upstream (site 5111) because we could not exclude the possibility that liming influenced the lower reaches of river Häggingån, through leakage through the wetlands in between. The unlimed water chemistry at the two sites was very similar, however, and no statistically significant differences between the two could be detected for any chemical parameters (Table 1, Fig. 3).

\subsection{Sampling}

Climate data were collected from the two nearest weather stations within the Swedish network (http://www.smhi.se/ klimatdata/meteorologi/dataserier-2.1102), Särna and Sveg, located approximately $40 \mathrm{~km}$ southwest and east of the study area, respectively. During 1975-1993, snow core samples were collected in Plexiglas tubes at $1000 \mathrm{~m}$ (Häggingfjället site), $800 \mathrm{~m}$ (Djursvålen site), $620 \mathrm{~m}$ (Djursvallen site) and $400 \mathrm{~m}$ (Sveg site) above sea level (Fig. 1). Sampling was performed each year in early April, before any visible snow melting had occurred. The snow was collected in polyethylene bags, and after melting the $\mathrm{pH}$ was immediately determined. Starting in 1983, precipitation was collected monthly as total deposition in polyethylene samplers at the Djursvallen site. Stream water samples were generally collected monthly, but sometimes daily and weekly; the samples were collected directly into polypropylene bottles for trace metal analysis and into polyethylene bottles for general water chemistry analyses. The sample bottles for trace metals were cleaned by soaking in $6 \mathrm{M}$ hydrochloric acid for three days at $40^{\circ} \mathrm{C}$ and stored with $0.05 \mathrm{M}$ nitric acid for at least one week until use. Before use, the bottles were rinsed with ultrapure deionised water (Milli-Q).

\subsection{Chemical analyses}

All chemical analyses were performed according to Swedish standard methods (SIS, Swedish Standards Institute), and subsequently, European standard methods (CEN, European Committee for Standardization). Snow $\mathrm{pH}$ was determined on site and water $\mathrm{pH}$ after the samples had been transported overnight to the laboratory in Stockholm. A combined glass electrode (Radiometer analytical, $\mathrm{Red} \mathrm{rod}, \mathrm{Ag} / \mathrm{AgCl}$ reference electrode) and liquid electrolyte $(\mathrm{KCl})$ was used for all samples. Major cations were determined by air-acetylene flame AAS (Varian), and from 2008 to present by ICP-AES 
Table 1. Latitude, longitude and mean, 5 and 95 percentiles of key water chemical variables during unlimed and limed periods of the stream-sampling stations in the Lofsdalen area, province of Jämtland.

\begin{tabular}{|c|c|c|c|c|c|c|c|c|c|c|c|}
\hline $\begin{array}{l}\text { Station nr and stream name } \\
\text { Lat-Long }\end{array}$ & $\begin{array}{l}\text { Liming status } \\
\text { Sampling period }\end{array}$ & & $\mathrm{pH}$ & $\begin{array}{r}\text { Alk } \\
\text { meq } \mathrm{L}^{-1}\end{array}$ & $\begin{array}{r}\text { ANC } \\
\text { meq } L^{-1}\end{array}$ & $\begin{array}{r}\mathrm{BC}^{*} \\
\text { meq } \mathrm{L}^{-1}\end{array}$ & $\begin{array}{r}\mathrm{SO}_{4}^{*} \\
\text { meq } \mathrm{L}^{-1}\end{array}$ & $\begin{array}{r}\text { TOC } \\
\mathrm{mg} \mathrm{L}^{-1}\end{array}$ & $\begin{array}{r}\mathrm{Fe} \\
\mu \mathrm{g} \mathrm{L}^{-1}\end{array}$ & $\mu \mathrm{g} \mathrm{L}^{-1}$ & $\mu \mathrm{g} \mathrm{L}^{\mathrm{Al}}$ \\
\hline \multirow{6}{*}{$\begin{array}{l}5004 \text { Djursvasslan } \\
62.0285^{\circ} \mathrm{N}-13.4885^{\circ} \mathrm{E}\end{array}$} & Unlimed & Mean & 6.05 & 0.186 & 0.331 & 0.374 & 0.043 & 9.0 & 3256 & 482 & 124 \\
\hline & 1981-1985 & $5 \%$ & 4.68 & -0.010 & 0.055 & 0.095 & 0.019 & 2.1 & 390 & 10 & 20 \\
\hline & & $95 \%$ & 7.46 & 0.840 & 0.820 & 0.867 & 0.079 & 16.0 & 10300 & 960 & 442 \\
\hline & Limed & Mean & 6.93 & 0.351 & 0.456 & 0.476 & 0.020 & 10.2 & 603 & 66 & 59 \\
\hline & 1985-2010 & $5 \%$ & 6.10 & 0.050 & 0.135 & 0.149 & $<0.010$ & 3.3 & 250 & 11 & 16 \\
\hline & & $95 \%$ & 7.55 & 0.810 & 0.890 & 0.927 & 0.048 & 19.0 & 1290 & 230 & 116 \\
\hline \multirow{9}{*}{$\begin{array}{l}\text { 5005 Hammarbäcken } \\
62.0402^{\circ} \mathrm{N}-13.5670^{\circ} \mathrm{E}\end{array}$} & Unlimed & Mean & 5.68 & 0.051 & 0.119 & 0.176 & 0.056 & 13.5 & 3090 & 302 & 151 \\
\hline & 1983-1984 & $5 \%$ & 4.47 & -0.010 & 0.045 & 0.075 & 0.018 & 8.9 & 210 & 11 & 35 \\
\hline & & $95 \%$ & 7.05 & 0.180 & 0.205 & 0.238 & 0.098 & 18.0 & 47000 & 1390 & 400 \\
\hline & Limed & Mean & 6.41 & 0.125 & 0.216 & 0.245 & 0.029 & 10.6 & 750 & 81 & 89 \\
\hline & 1985-1995 & $5 \%$ & 5.47 & 0.020 & 0.090 & 0.125 & 0.009 & 4.8 & 160 & 8 & 39 \\
\hline & & $95 \%$ & 6.97 & 0.270 & 0.354 & 0.382 & 0.048 & 20.0 & 1800 & 166 & 191 \\
\hline & Terminated liming & Mean & 6.37 & 0.119 & 0.214 & 0.231 & 0.017 & 13.0 & 793 & 62 & 106 \\
\hline & 1996-2010 & $5 \%$ & 5.18 & -0.003 & 0.100 & 0.125 & $<0.010$ & 4.8 & 295 & 11 & 39 \\
\hline & & $95 \%$ & 7.10 & 0.270 & 0.304 & 0.338 & 0.035 & 26.4 & 1390 & 178 & 191 \\
\hline \multirow{6}{*}{$\begin{array}{l}5006 \text { Djursvålsbäcken } \\
62.0063^{\circ} \mathrm{N}-13.3709^{\circ} \mathrm{E}\end{array}$} & Unlimed & Mean & 5.67 & 0.073 & 0.104 & 0.140 & 0.036 & 9.1 & 448 & 33 & 97 \\
\hline & 1982-1992 & $5 \%$ & 4.21 & -0.010 & 0.015 & 0.053 & 0.009 & 1.0 & 48 & 1 & 19 \\
\hline & & $95 \%$ & 7.10 & 0.330 & 0.370 & 0.408 & 0.059 & 24.0 & 1470 & 140 & 197 \\
\hline & Limed & Mean & 6.63 & 0.153 & 0.229 & 0.251 & 0.022 & 9.5 & 345 & 31 & 82 \\
\hline & $1992-2010$ & $5 \%$ & 5.60 & 0.020 & 0.099 & 0.129 & $<0.010$ & 1.7 & 105 & 2 & 21 \\
\hline & & $95 \%$ & 7.20 & 0.390 & 0.503 & 0.525 & 0.048 & 24.0 & 1010 & 132 & 148 \\
\hline \multirow{6}{*}{$\begin{array}{l}5009 \text { Lofsån } \\
\text { (Outlet river) } \\
62.0379^{\circ} \mathrm{N}-13.5127^{\circ} \mathrm{E}\end{array}$} & Unlimed & Mean & 6.17 & 0.092 & 0.149 & 0.196 & 0.046 & 10.4 & 574 & 114 & 101 \\
\hline & 1981-1985 & $5 \%$ & 5.17 & -0.005 & 0.070 & 0.108 & 0.009 & 7.7 & 140 & 13 & 59 \\
\hline & & $95 \%$ & 6.91 & 0.235 & 0.270 & 0.329 & 0.068 & 14.0 & 2080 & 490 & 196 \\
\hline & Limed & Mean & 6.63 & 0.170 & 0.237 & 0.268 & 0.031 & 8.1 & 375 & 66 & 71 \\
\hline & 1985-2010 & $5 \%$ & 6.13 & 0.060 & 0.140 & 0.172 & 0.009 & 5.5 & 130 & 13 & 42 \\
\hline & & $95 \%$ & 7.00 & 0.330 & 0.389 & 0.410 & 0.048 & 11.5 & 766 & 195 & 108 \\
\hline 5110/5111 Häggingån & Unlimed & Mean & 6.06 & 0.060 & 0.114 & 0.155 & 0.036 & 8.4 & 212 & 17 & 89 \\
\hline (Unlimed references) & 1984-2010 & $5 \%$ & 4.50 & -0.023 & 0.020 & 0.062 & $<0.010$ & 1.0 & 33 & 1 & 23 \\
\hline $62.0116^{\circ} \mathrm{N}-13.3666^{\circ} \mathrm{E}$ & & $95 \%$ & 7.03 & 0.230 & 0.291 & 0.318 & 0.059 & 28.0 & 680 & 50 & 177 \\
\hline
\end{tabular}

(Varian Vista). The anions were determined using titrimetric and spectrometric methods until 1984, and then by ion chromatography (Tecator, Dionex). The total organic carbon (TOC) was determined using TOC-analysers Carlo-Erba, Astro, and from 2006 to present, Shimadzu TOC-V CPH. Silica, nitrogen and phosphorus were determined using spectrometry in continuous-flow autoanalysers. Trace metals were determined by GFAAS (Perkin-Elmer Zeeman 3030), and from 1995 to present, they were determined using ICP-MS (Sciex Elan 5000 until 2006 and thereafter Thermo X-series 2). Aluminium speciation was performed by automated cation exchange and spectrometric determination of the pyrocatechol complex (Driscoll, 1984; Andrén and Rydin, 2009).

Quality assurance of all analytical results included continuous use of internal and certified reference samples, and by following further routines specified in the laboratory accreditation (Swedac accreditation no. 1295, 1993). The analytical laboratory was a part of the Swedish Environmental Protection Agency until 1 July 1992, when it was reorganised into the new Department of Applied Environmental Science (ITM), Stockholm University. The chemical analyses of precipitation from the Djursvallen site have been per- formed within the national air and precipitation chemistrymonitoring network since 1983 (http://www.ivl.se).

\subsection{Data analysis}

The fractions of sulfate, sodium, calcium and magnesium of non-marine origin were calculated by subtracting their seawater concentration relative to chloride (e.g. non-marine sulfate in meq $\left.\mathrm{L}^{-1}: \mathrm{SO}_{4}^{* 2-}=\mathrm{SO}_{4}^{2-}-0.103 \times \mathrm{Cl}^{-}\right)$. In the following text, ion charges are omitted for clarity. Data analyses were performed using the SPSS and JMP statistical packages. The nonparametric seasonal Mann-Kendall test was used to test the significance of trends. The method is suitable for data with strong seasonal variation and for data that are not normally distributed or contain extreme observations. For the magnitude of the trends, Theil's slope was estimated for the time series on a yearly basis, for example, an increase or decrease by $\mathrm{mg} \mathrm{L}^{-1} \mathrm{yr}^{-1}$ or meq $\mathrm{L}^{-1} \mathrm{yr}^{-1}$ (Helsel and Hirch, 1992). 


\section{Results}

\subsection{Trends in temperature and precipitation}

The weather observations recorded at the two nearby weather sites are probably representative also for the study area, as both sites showed very similar temporal patterns of annual mean temperature and precipitation (Fig. 2), although air temperature was consistently somewhat lower at the Särna site than at the Sveg site. There was a significant long-term increase in temperature at both sites from 1975 to 2012, 0.038 and $0.057^{\circ} \mathrm{C} \mathrm{yr}^{-1}$, respectively, with a mean trend of $0.050^{\circ} \mathrm{C} \mathrm{yr}^{-1}$ ( $p=0.014$, Theil's slope). No significant long-term trend in precipitation could be detected during this period but there was a clear increase from 1975 to 1985 when annual temperature reached a minimum after a decade of more or less decreasing temperatures (Fig. 2).

\section{$3.2 \mathrm{pH}$ in snow}

In 1975 , the $\mathrm{pH}$ of the snow was approximately 5.4 at all altitudes and was relatively unaffected by acidic deposition (Fig. 2), but the pH substantially decreased during the three following years, reaching 4.0 in 1978 at $1000 \mathrm{~m}$ a.s.l. Starting at approximately the same levels in 1975 and 1976, the $\mathrm{pH}$ dropped faster at the higher altitudes $800-1000 \mathrm{~m}$ a.s.l., while the lowest site at $400 \mathrm{~m}$ generally had $\mathrm{pH}$ values that were approximately 0.5 units higher. The highest precipitation occurred at the highest altitudes, $800-1000 \mathrm{~m}$, where the snow depth generally was approximately $40-80 \mathrm{~cm}$ greater, than at $400 \mathrm{~m}$ (Fig. 2). From 1978, pH increased again temporarily to $4.8-5.0$ and dropped back to $4.0-4.8$ in 1982 . After a period of considerable interannual variation during the 1980s, snow pH appeared to stabilize and slowly increase, at least at the highest altitudes (Fig. 2).

\subsection{Deposition}

The non-marine fraction $\left(\mathrm{SO}_{4}^{*}\right)$ of annual sulfate deposition, measured at $620 \mathrm{~m}$ a.s.l., substantially decreased during the 1980s, from $80 \mathrm{keq} \mathrm{km}^{-2}$ in 1985 to 25 in 1990 (Fig. 2). The decrease continued but at a slower rate during the 1990s. During the last decade, the sulfate deposition has stabilized around $5 \mathrm{keq} \mathrm{km}^{-2} \mathrm{yr}^{-1}$. In contrast, the nitrate deposition has varied around approximately $10 \mathrm{keq} \mathrm{km}^{-2} \mathrm{yr}^{-1}$ during the entire $25 \mathrm{yr}$ study period. The non-marine Ca deposition decreased during the 1980s and has then been relatively stable at approximately $5 \mathrm{keq} \mathrm{km}^{-2} \mathrm{yr}^{-1}$.

\subsection{Stream water chemistry}

\subsubsection{Long-term trends}

The drastic drop in snow $\mathrm{pH}$ was reflected in a decreased $\mathrm{pH}$ in the stream waters at spring flood, exemplified with Djursvålsbäcken (5006) in Fig. 2. Stream water chemistry

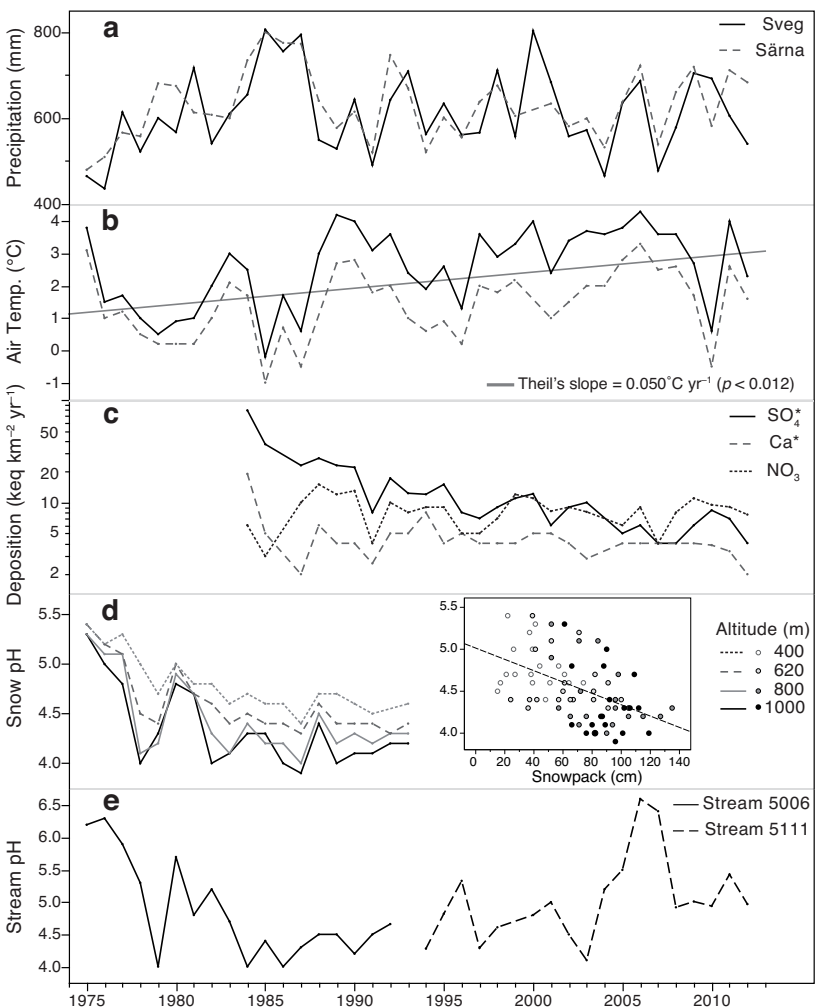

Fig. 2. Overview of time series: (a) and (b) annual precipitation and annual mean temperature at two weather monitoring stations $40 \mathrm{kmE}$ (Sveg) and SW of the Study area. The straight line represents Theil's slope fitted to the mean of data from both temperature curves. (c) Annual deposition of $\mathrm{SO}_{4}^{*}, \mathrm{NO}_{3}$, and $\mathrm{Ca}^{*}$ at the precipitation monitoring site Djursvallen, close to stream Djursvasslan (5004) in Lofsdalen, 1984 to 2009 (“*” indicates the non-marine fractions). Note that the $y$ axis is log-transformed to facilitate comparison. (d) Snow $\mathrm{pH}$ at different altitudes above seal level. Snow cores were collected in April 1975-1993 (data from Erik Olofsson, Sveg, municipality of Härjedalen). The embedded graph illustrates the relationship between $\mathrm{pH}$ and snow depth. (e) Annual min $\mathrm{pH}$ of stream water from two nearby stream-sampling stations; Djursvålsbäcken (5006) before liming and never limed Övre Häggingån (5111).

generally followed the long-term trends in precipitation, but with local variation among the different streams. Water $\mathrm{pH}$ increased from 1994 to 2010 by $0.03 \mathrm{yr}^{-1}$ in the unlimed reference stream, Övre Häggingån (5111; Table 2, Fig. 2). However, the seasonal variation was considerable, and acid episodes with $\mathrm{pH}$ values less than 5.0 still occurred during the most recent years (Fig. 3).

Generally, the sulfate concentration in the streams decreased, but the rate of change was slower compared to the deposition trend, especially during the 1980s and 1990s. Since the late 1990s, sulfate in the streams has increased (Fig. 4). During the almost $30 \mathrm{yr}$ study period, the sulfate mean level has decreased by approximately $0.03 \mathrm{meq} \mathrm{L}^{-1}$, which corresponds to an average annual 
Table 2. Theil's slope estimates of long-term trends of non-marine sulfate $\left(\mathrm{SO}_{4}^{*}\right)$, total organic carbon (TOC) and $\mathrm{pH}$ in the streams during the whole period and during 2000-2010. The probabilities $(p)$ of change are associated with the seasonal Mann-Kendall test; significant changes in bold $(p<0.05)$.

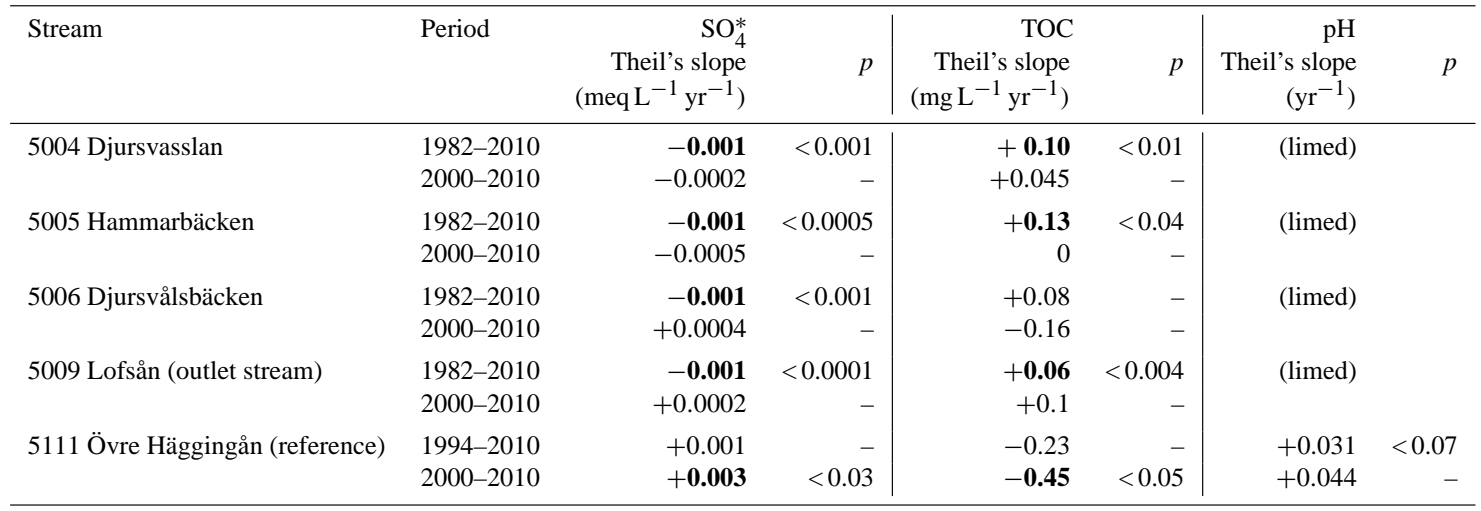

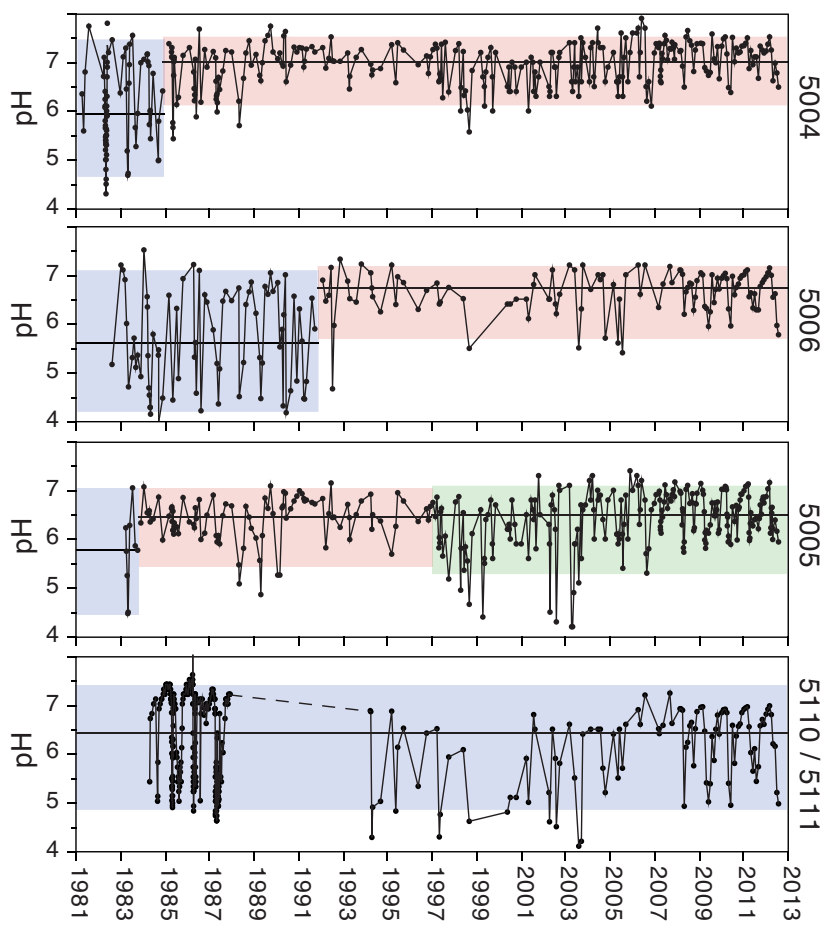

Fig. 3. Fluctuations of $\mathrm{pH}$ in the streams 5004, 5005, 5006, and 5110/5111. Blue areas mark the unlimed periods, red areas the limed periods, and green area the period after terminated liming. Stream 5111 is an unlimed reference stream sampled 1994-2012, Station 5110 located downstream station 5111 was sampled 1984 1987 (later values omitted as the sampling point may have been influenced by a limed tributary.

decrease of $1 \mu \mathrm{eqL} \mathrm{L}^{-1}$ (Theil's slope estimator; Table 2). However, during the period 2000-2010 this decrease cannot be confirmed statistically, and in Häggingån (5111) $\mathrm{SO}_{4}^{*}$ increased with $3 \mu \mathrm{eq} \mathrm{L} \mathrm{L}^{-1} \mathrm{yr}^{-1}$ (Table 2). Similar to the relatively stable nitrate deposition, nitrate concentration in the stream waters showed no long-term trend during the study period.

The TOC concentration is relatively high in most of these streams (Table 1) because of upstream wetlands. TOC generally increased until approximately 2002 (Fig. 4), and Theil's slope estimates showed an annual increase of approximately $0.1 \mathrm{mg} \mathrm{L}^{-1}$ in four of the streams during the study period (Table 2). Generally, the temporal patterns of the sulfate and TOC concentrations are inversely related and there is an overall negative correlation between $\mathrm{SO}_{4}^{*}$ and TOC $\left(R^{2}=\right.$ 0.67, Fig. 4).

\subsubsection{Acid episodes}

Monthly median ion concentrations during unlimed conditions reveal differences in seasonality among the major ions (Fig. 5). The concentrations of non-marine base cations $\left(\mathrm{BC}^{*}\right)$ were somewhat higher during the groundwater dominated winter months and lowest during the spring flood. Silica presented the same seasonal variation but with a higher amplitude (Fig. 5). In contrast, TOC was highest during the summer and decreased during the winter. $\mathrm{SO}_{4}^{*}$ showed relatively small seasonal variation overall, with the highest median values in April, which then decreased during the spring to summer and increased again during the snow-covered period (Fig. 5).

Acid episodes, when the alkalinity may be totally depleted and the $\mathrm{pH}$ reach as low as 4.0 despite the relatively high buffer capacity of the baseflow water (base flow alkalinity is often $0.5-1.0 \mathrm{meq} \mathrm{L}^{-1}$ ), occurred frequently during highflow events. The unlimed reference stream Övre Häggingån (5111) had repeated episodes with $\mathrm{pH}$ of approximately 5.0 or below from 1984 to 2012. Similarly, in the stream Hammarbäcken (5005), where the lime treatment was terminated in 1995, episodes with negative alkalinity and $\mathrm{pH}$ below 5.0 occurred during 1998-2005, after which the episodes have been less severe (Fig. 3). To evaluate the main causes of the 


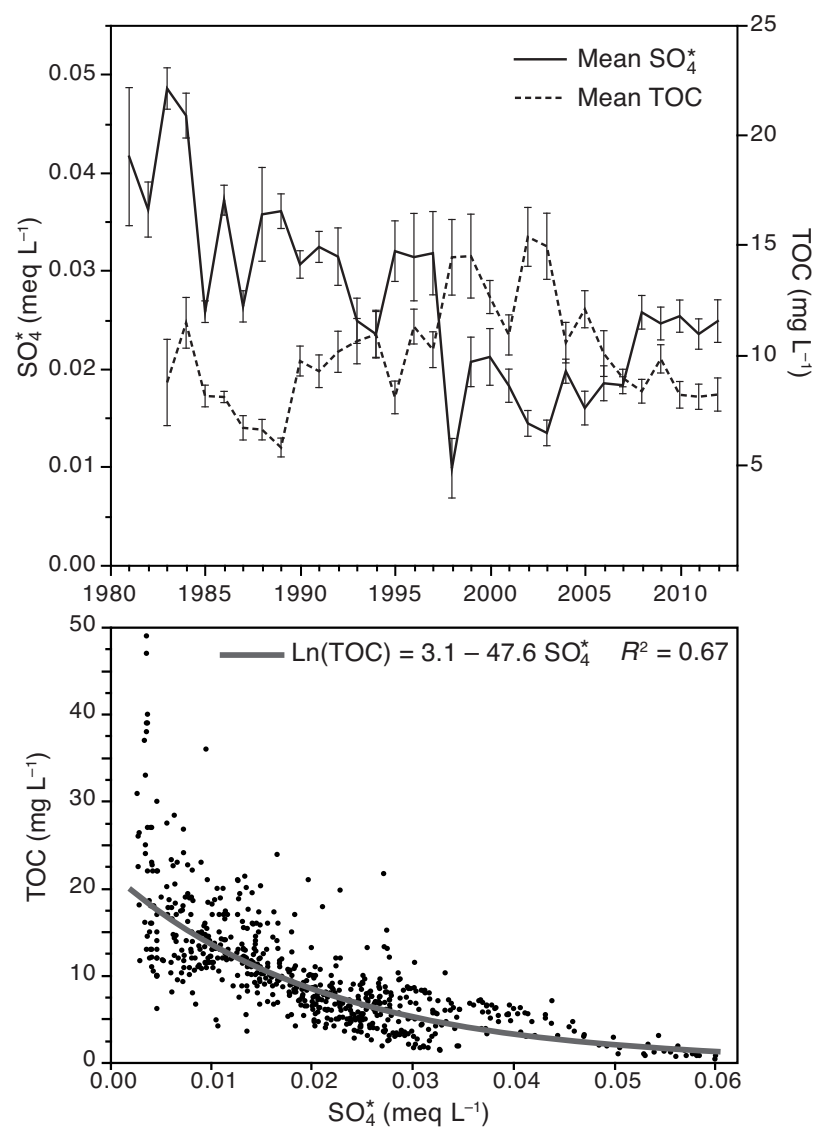

Fig. 4. Upper panel: trends in non-marine sulfate $\left(\mathrm{SO}_{4}^{*}\right)$ and total organic carbon (TOC) in the streams during the study period (annual mean, standard error). Lower panel: correlation between TOC and $\mathrm{SO}_{4}^{*}$ concentrations in stream water. Each point represents a single sample. Data include the streams 5004 (with the two tributaries 5002, 5003), 5005, 5006, 5009, and 5111.

still frequent acid episodes, the changes in concentrations of the major ions between the base flow and high flow were evaluated for three streams; Djursvasslan (5004), Djursvålsbäcken (5006), from the period before liming, and Övre Häggingån (5111), the unlimed reference stream. The annual changes of $\mathrm{BC}^{*}, \mathrm{SO}_{4}^{*}, \mathrm{Cl}, \mathrm{NO}_{3}$, and organic anions were calculated as the difference between concentrations at high flow and baseflow. Organic anions were defined as the difference between major cations $(\mathrm{Ca}, \mathrm{Mg}, \mathrm{Na}, \mathrm{K})$ and anions (alkalinity, $\mathrm{SO}_{4}, \mathrm{Cl}, \mathrm{NO}_{3}$ ) in meq $\mathrm{L}^{-1}$, and we identified the annual high flow and baseflow concentrations by the timing of maximum and minimum ANC, respectively. The median $\mathrm{pH}$ values dropped between 1.0 to 1.5 units during high flow periods, and the loss of ANC was $0.1-0.4 \mathrm{meq} \mathrm{L}^{-1}$ (Fig. 6).

The largest change was observed for $\mathrm{BC}^{*}$ in all three streams, of -0.1 to $-0.36 \mathrm{meq} \mathrm{L}^{-1}$, which indicates a considerable dilution of the $\mathrm{BC}^{*}$ at high flow. In contrast, sulfate did not exhibit any large changes at peak flow; for most peak flow events, it remained unchanged or exhibited a slight di-

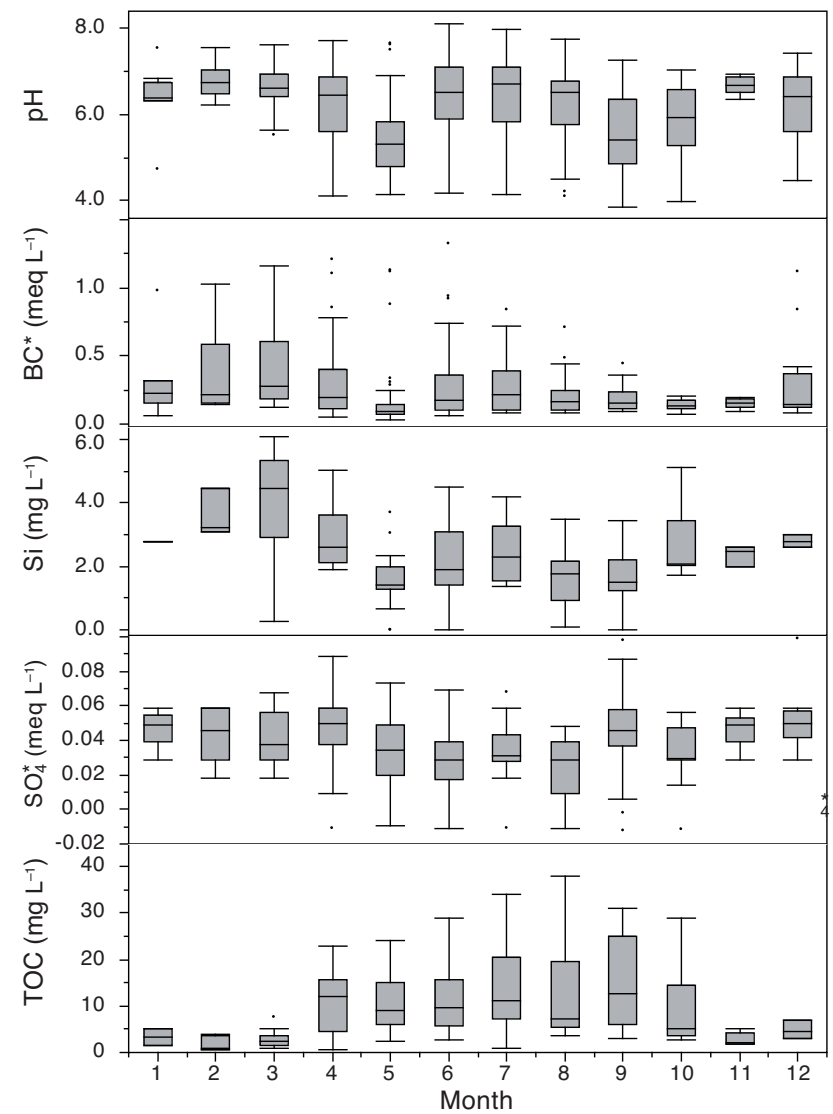

Fig. 5. Seasonal variation in water chemical parameters at unlimed conditions. Boxes represent 25, 50 and 75 percentiles and whiskers represent 10 and 90 percentiles of monthly concentrations measured in all streams for all years.

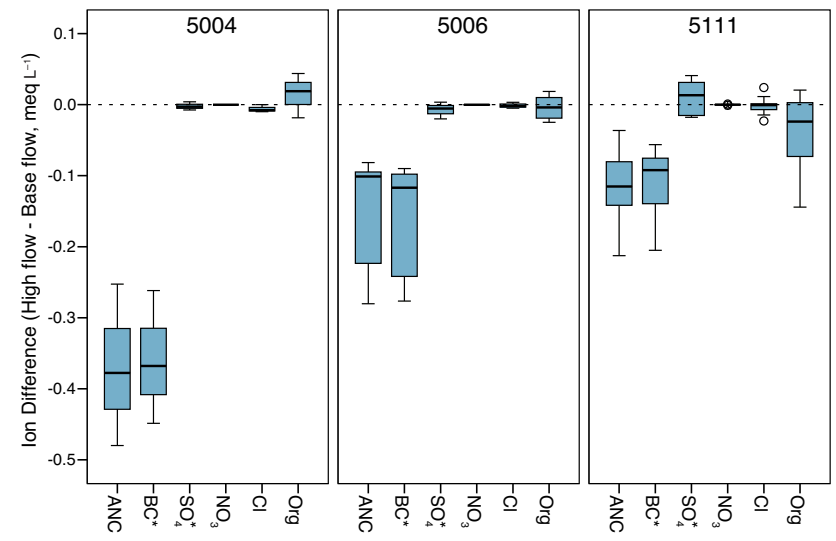

Fig. 6. Loss of acid neutralizing capacity (ANC) and concurrent changes in major ions and organic anions (Org) in unlimed streams at high flow compared to base flow (high flow minus base flow, i.e. negative numbers indicate dilution and positive numbers indicate enrichment at high flow).

lution. In the reference stream Övre Häggingån (5111), an enrichment of sulfate was observed during the majority of 
high flow periods (i.e. a median ion difference above zero). The concentration of organic anions slightly increased in stream 5004 Djursvasslan, remained unchanged in stream 5006 Djursvålsbäcken, and was diluted in stream 5111 Ö Häggingån. Chloride and nitrate ions underwent only minor concentration changes during high flow (Fig. 6).

\subsubsection{Chemical effects of liming}

The lime treatment of the wetlands was effective in stabilising the water chemistry and counteracting the acid episodes during the spring flood and rainy periods. Since the beginning of the treatment, the limed streams have retained some alkalinity, even during the high flow periods, and the $\mathrm{pH}$ rarely reached below 5.5 for several years after treatment (Fig. 3). The former extremely high peak values of $\mathrm{Fe}, \mathrm{Mn}$ and $\mathrm{Al}$ during high flow, for example, in Djursvasslan (5004) and its tributaries, have not returned since liming began (Fig. 7). Trace elements such as $\mathrm{Cd}$ also showed lower concentrations and less seasonal variations after liming (Fig. 7). As expected, inorganic monomeric $\mathrm{Al}$ (Ali) was negatively correlated to $\mathrm{pH}$, and the highest Ali concentrations occurred during acid episodes, especially in the unlimed streams (Fig. 8). Some elevated concentrations also occurred in stream 5005 Hammarbäcken after the liming was terminated in 1995 along with returning acid episodes. Negative $\mathrm{pH}$ correlations were also observed for other typically positively charged elements such as $\mathrm{Cd}$ and $\mathrm{Zn}$, while elements that mainly occur as oxoanions, such as Mo, showed a positive correlation with $\mathrm{pH}$; the lowest concentrations were found in the unlimed streams and in the reacidifying stream 5005 (Fig. 8).

\section{Discussion}

\subsection{Climate, precipitation chemistry and deposition}

The effects of acid precipitation have been documented in Sweden since the 1960s, primarily in south-western Sweden, the area most affected by long-range airborne pollutants from the European continent (Almer et al., 1974; Odén, 1968). The more northern part of Sweden appeared to be less affected, at least until the mid-1970s, when observations of low $\mathrm{pH}$ values in the snow profiles followed by acid episodes in mountain streams were reported, for example, in the area studied here, and further north in Sweden, in the province of Västerbotten (Bjärnborg, 1983). In our study area, there was a drastic decrease in snow pH during the 1970s, especially at higher altitudes. This dramatic change may be connected to a decreased temperature 1975 to 1980 , and an increased precipitation with a relatively higher amount deposited as snow during November to May (Fig. 2). Another factor of importance is the dominating wind direction. The lowest $\mathrm{pH}$ of precipitation in our study area was generally associated with southeasterly winds, which indicates an influence from

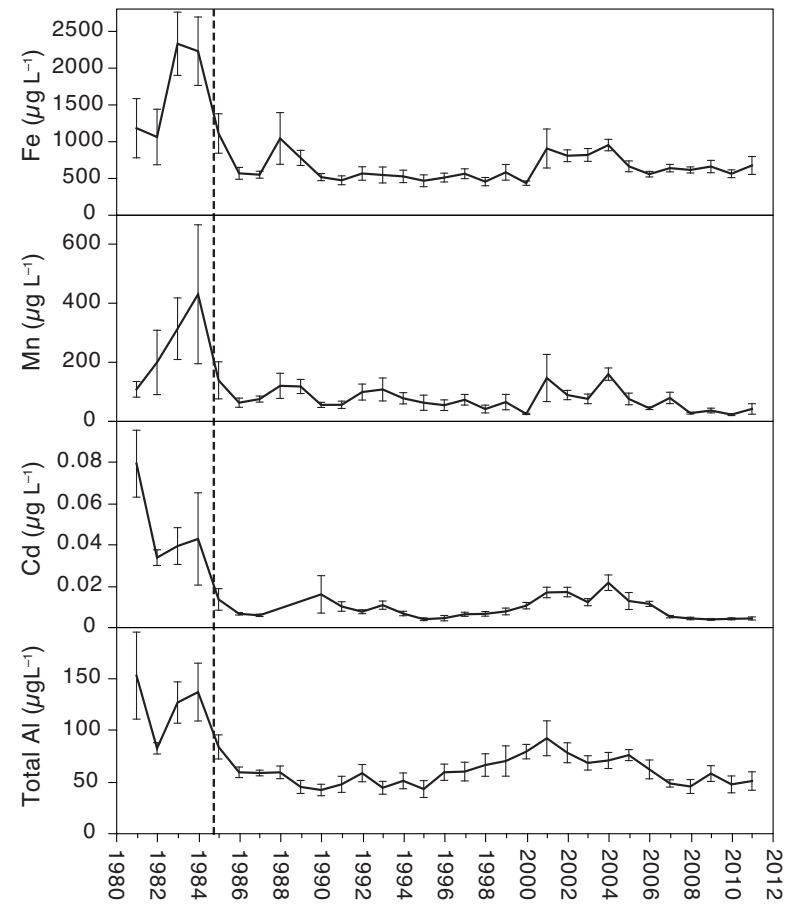

Fig. 7. Concentrations (annual means, $\pm \mathrm{SD}$ ) of $\mathrm{Fe}, \mathrm{Mn}, \mathrm{Cd}$, and $\mathrm{Al}$ in R. Djursvasslan (5004) and its two tributaries (5002, 5003) before and after the start of liming, indicated by the vertical dashed line.

domestic emission sources and from long-range air pollution from central and Eastern Europe. The nearby mountain range at the Norwegian border likely somewhat protects the area from westerly winds that bring pollutants from Western Europe. During some occasions (e.g. in May 1981) $\mathrm{pH}$ as low as 3.6-3.7 was recorded in the throughfall at $800 \mathrm{~m}$ a.s.l. (data from Erik Olofsson, Sveg, personal communication, 1990). The prevailing wind direction over northern Sweden during 1951-2008 was reported to be mostly south to southwest, but there were also some years when southeasterly winds dominated (e.g. 1981) (Wern and Bärring, 2009). Annual mean air temperatures (Fig. 2) were also positively correlated to the winter (December-March) North Atlantic Oscillation Index (NAO; http://www.cru.uea.ac.uk/cru/data/nao; $R^{2}$ values 0.19 and 0.25 ), indicating different origin of the air masses traversing the area during winter.

Similar to the general trend in many parts of Europe, sulfur deposition rapidly decreased during the 1980s from approximately 80 to $20 \mathrm{keq} \mathrm{km}^{-2} \mathrm{yr}^{-1}$. The decrease continued more slowly during the 1990 s to approximately $10 \mathrm{keq} \mathrm{km}^{-2} \mathrm{yr}^{-1}$. During the last ten years, the sulfur deposition has been relatively unchanged and even showed a slight increase. The sulfur emission protocols agreed upon in Europe (e.g. UNECE, 1987) had a markedly positive effect, especially during the 1980s, but today's remaining emissions are likely more difficult to decrease further, which causes the earlier decreasing 


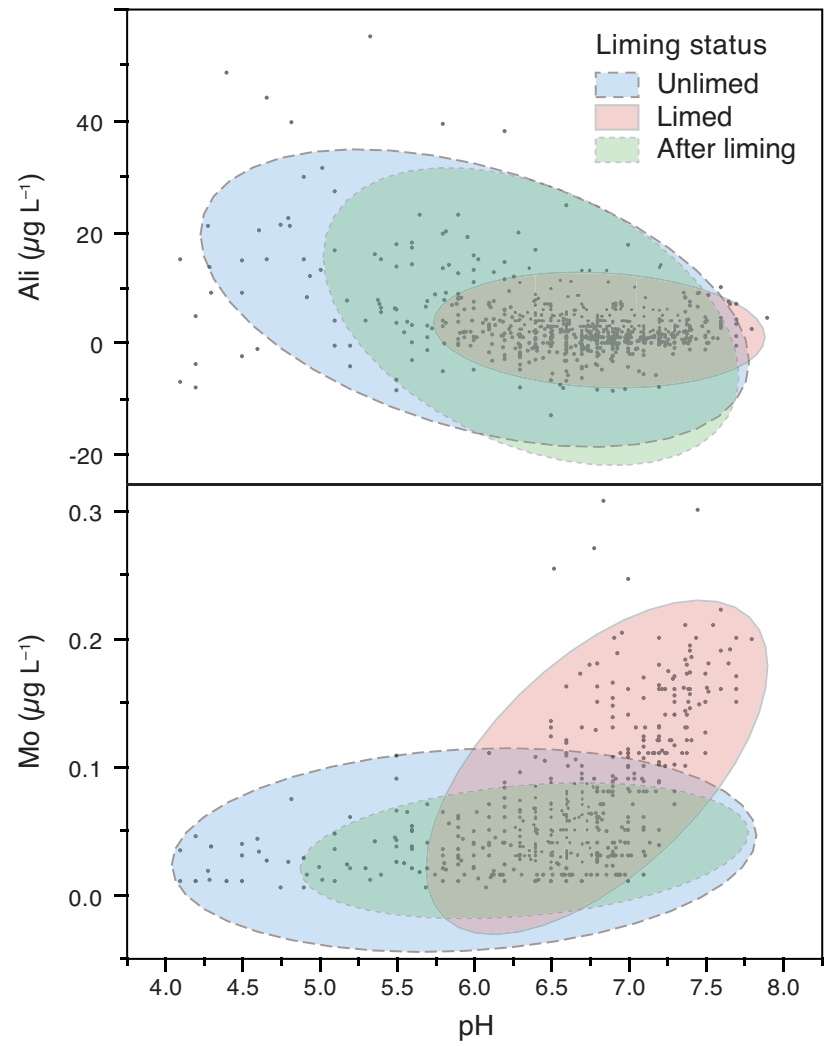

Fig. 8. The influence of $\mathrm{pH}$ on inorganic aluminium (Ali, upper panel) and molybdenum (lower panel) concentrations in stream water. The bivariate normal density ellipses $(90 \%)$ illustrate the sign and strength of the correlation under unlimed conditions (blue areas), limed conditions (red areas) and after that liming was terminated in 1995 (green areas).

trend of sulfate also in the surface waters to level out or increase (Figs. 4 and 10).

The deposition of $\mathrm{Ca}^{*}$ and $\mathrm{SO}_{4}^{*}$ is now roughly equivalent, providing potential for further recovery of water quality from the effects of earlier excess sulfate deposition and the depletion of cations such as $\mathrm{Ca}$ and $\mathrm{Mg}$ in the soil.

Some influence of the climatic conditions on the nitrogen fractions in air during the winter (December-March) was observed, indicated by a correlation between the NAO-index and the nitrate concentration in the precipitation $\left(R^{2}=0.28\right.$, $p<0.01)$ and a weaker correlation with ammonium $\left(R^{2}=\right.$ $0.14)$. There were also a general tendency towards higher $\mathrm{pH}$ values and lower sulfate concentrations in the precipitation during periods with a low NAO-index, indicating an influence of relatively cleaner Arctic air masses.

\subsection{Water chemistry: long-term trends}

Like most of Sweden, the investigated area is dominated by non-calcareous bedrock, and thus its surface waters are sensitive to acid precipitation. Consequently, the increased acid

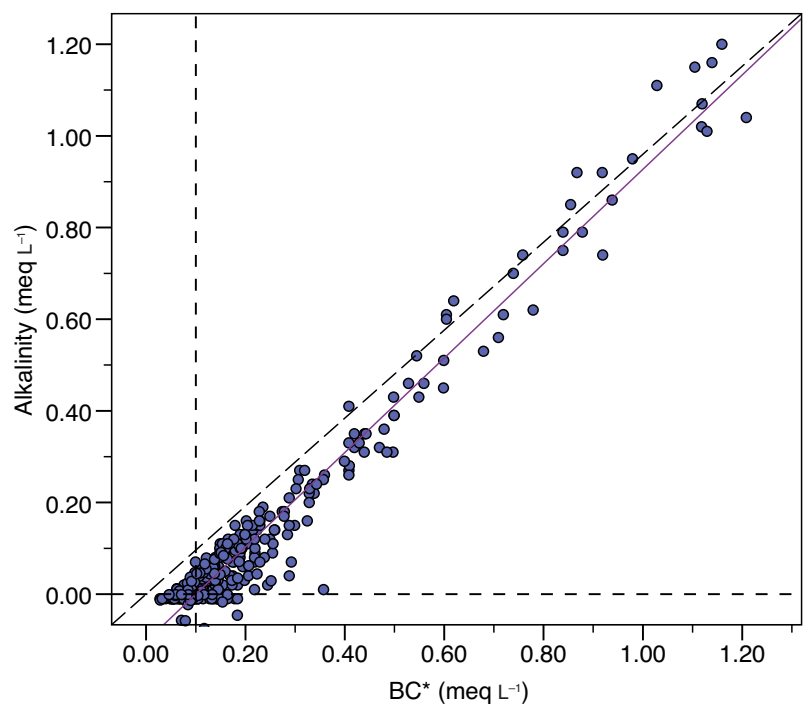

Fig. 9. An average deficit of alkalinity of approximately $0.1 \mathrm{meq} \mathrm{L}^{-1}$ was found before liming of the stream waters.

deposition caused a deficiency in alkalinity of approximately $0.1 \mathrm{meq} \mathrm{L}^{-1}$ compared to the levels of $\mathrm{BC}^{*}$ under unlimed conditions (Fig. 9). The increasingly acidic precipitation in 1970s in these relatively remote but acid-sensitive areas gave a fast response in the quality of the runoff surface waters (Jacks et al., 1986). Figure 2 shows an example from the unlimed Djursvålsbäcken (5006), with a relatively close agreement between the $\mathrm{pH}$ in the catchment snow and the minimum $\mathrm{pH}$ in the stream water during the spring floods. The squared correlation coefficients $\left(R^{2}\right)$ between stream water minimum $\mathrm{pH}$ and snow $\mathrm{pH}$ were 0.84 for snow at $600 \mathrm{~m}$, 0.68 at $800 \mathrm{~m}$, and 0.57 at $1000 \mathrm{~m}$ a.s.l., respectively.

The long-term trend in the precipitation chemistry is reflected in the water chemistry of the brooks (Tables 1 and 2). Theil's slope estimates generally indicate an annual decrease of sulfate with approximately $1 \mu \mathrm{eq} \mathrm{L}{ }^{-1}$ for the study period as a whole, while no change can be detected for the years 2000-2010. In contrast, the reference stream 5111, Övre Häggingån, shows an annual increase of $3 \mu \mathrm{eq} \mathrm{L}^{-1} 2000$ 2010. The general decline rate of stream water sulfate in this area is similar to trends observed in northern lakes but slower than for lakes in southern Sweden and Norway (Skjelkvåle et al., 2007).

Within the catchment of Djursvasslan (5004), the longterm decline in both winter $\mathrm{SO}_{4}^{*}$ deposition (DecemberApril) and $\mathrm{SO}_{4}^{*}$ concentration in snow from the 1980 s until today, is reflected in the stream water $\mathrm{SO}_{4}^{*}$ concentration, but with an apparent time lag of 5 to $10 \mathrm{yr}$ (Fig. 10). In most years the sulfate concentration in the catchment snow is higher than in the stream water spring flood concentration, which indicates that the precipitation-derived sulfate is the main source for the stream water sulfate. However, the sulfate concentration in this stream during high flow has occasionally 
exceeded the concentration in the snow, not only during the period of rapid decrease but also after the $\mathrm{SO}_{4}$ deposition has levelled out (Fig. 10). Using sulfur isotopes and sulfate concentrations in streams in northern Sweden, Mörth et al. (2008) found that the main stream water sulfate sources were sedimentary sulfides and anthropogenic sulfur. During snowmelt, anthropogenic sulfur from the snow and desorbing sulfate were the main sources of sulfur. We suggest that formerly deposited sulfate retained in the peatlands of the catchment may have contributed to the periodically excess stream water sulfate observed in this study. One possible explanation is periods with a deeper route of runoff because of less frozen soils. In addition, the decreasing acid deposition and the possibly increased soil water $\mathrm{pH}$, may cause a decreased sulfate absorption capacity of the soils, thereby releasing sulfate. Alternatively, at some occasions there might also have been a depletion of the sulfate content in the snowpack due to selective melting during the winter, even if the samples were collected before any visible snowmelt had occurred. The decreasing long-term trend of sulfate in the stream water has levelled off and our data suggest an increase since the late 1990s (Figs. 4 and 10). This may be an effect by climate change - both annual and especially winter mean air temperature have increased during the $30 \mathrm{yr}$ study period (Figs. 2 and 10) - and changed runoff routes because of a more shallow soil layer being frozen and also shorter periods of frost.

The overall long-term trends in sulfate and TOC are roughly opposite to each other, and there is an overall negative correlation between sulfate and TOC $\left(R^{2}=0.67\right.$, Fig. 4$)$. A similar relationship have been reported from other areas, e.g. lakes and streams in the UK as well as lakes in the US and Scandinavia (Erlandsson et al., 2008; Evans et al., 2005, 2006; Monteith et al., 2007; Winterdahl et al., 2011). In those studies, it was concluded that in addition to climate-related effects (Freeman, 2004; Weyhenmeyer and Karlsson, 2009; Jennings et al., 2010), there was a connection between the decreased acid deposition and the increased run-off of organic carbon to streams and lakes in regions previously affected by higher load of acidifying substances. The observed trend in organic carbon in our streams may thus be a result of changed acid deposition and also of a changing climate.

\subsection{Water chemistry: seasonal variations}

The hydrological regime of these catchments is characterised by very large seasonal variation in discharge into the streams, with a factor of more than 200 between base and high flow (Borg et al., 1995), causing substantial short-term variability in, for example, pH (Fig. 3). Before the acid deposition started to increase in the study area during the $1970 \mathrm{~s}, \mathrm{pH}$ at high flow was generally around 6.0 or higher. In stream 5006, pH during spring flood was 5.9-6.3 during 1975-1977 (Fig. 2). Similarly, in stream 5004, $\mathrm{pH}$ was relatively stable at 7.0 through the year, 1976, apart from at peak flow in May, when it decreased to 6.7. In 1979, $\mathrm{pH}$ at spring flood dropped

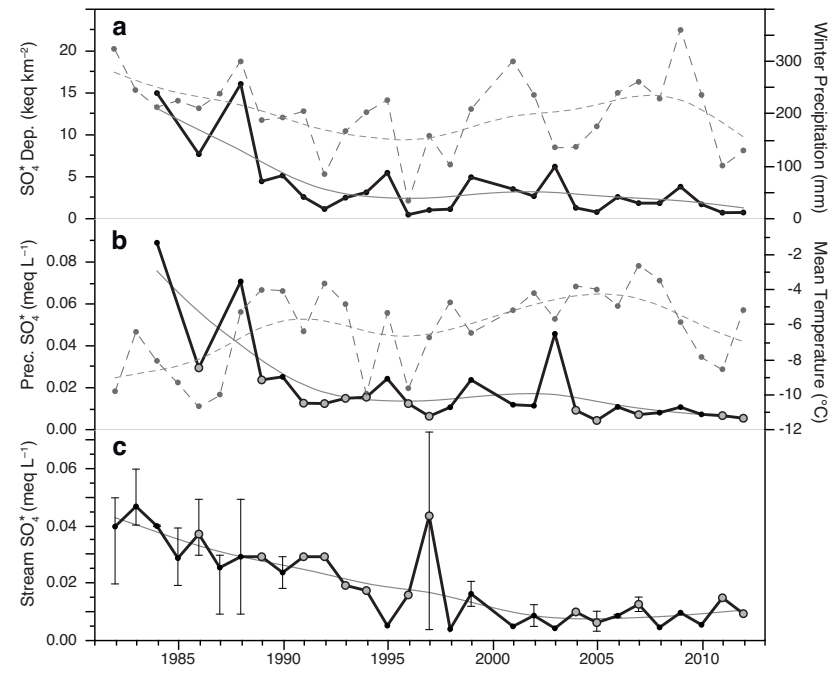

Fig. 10. Comparison of winter climate and deposition with nonmarine sulfate $\left(\mathrm{SO}_{4}^{*}\right)$ concentration in stream water after snow melt over 30 yr: (a) Total $\mathrm{SO}_{4}^{*}$-deposition and precipitation (dashed line) during November-Mar.; (b) $\mathrm{SO}_{4}^{*}$ - concentration in precipitation (snow) represented by precipitation weighted mean of monthly records Nov-March and mean air temperature (dashed line) November-March. (c) Mean $\mathrm{SO}_{4}^{*}$-concentration in R. Djursvasslan 5004) stream water during spring flood (May). Error bars cover the range for years with multiple samples taken during May. Grey, enlarged points indicate years with higher $\mathrm{SO}_{4}^{*}$ concentration in stream water after snowmelt than in winter precipitation. The thin trend lines are spline function fitted to the data. Air temperature is the average of the monthly mean temperatures recorded at the Sveg and Särna weather observatories (cf. Fig. 2). Precipitation and deposition data mainly originate from the Djursvallen precipitation monitoring station located close to the stream-sampling station. For years 1982-1983 and a few months where local observations were unavailable, missing data was imputed with the average of corresponding precipitation data from the Särna and Sveg observatories.

to 4.0 in that stream (Erik Olofsson, Sveg, personal communication, 1986). According to an estimation of reference conditions (year 1860) using the MAGIC library (Moldan et al., 2013), pH at high flow in the stream 5111, Häggingån would have been approximately 5.5 . The natural $\mathrm{pH}$ variation in these streams probably had smaller amplitude than what has been observed during the latest 30 years.

The streams are relatively well buffered during base flow but because of the acidic deposition they may lose all of their ANC in a few hours at rising discharge during the spring snow melt. Most of the severe episodes were associated with the spring flood following snow melt; in some years, the spring flood consisted of two or more flow peaks depending on the progress of the snow melt at lower and higher altitudes. Acid episodes caused by rainy periods in the summer and autumn, were occasionally observed. The seasonal pattern varies among the studied water chemistry variables. Base cations and $\mathrm{pH}$ are lowest during the high flow in May 
(Fig. 5). Silica exhibits approximately the same pattern as $\mathrm{BC}^{*}$, but with a larger amplitude. The highest concentrations were observed during the winter, suggesting a major groundwater contribution to the base-flow and a then dilution with runoff water during the spring flood. TOC exhibits the opposite pattern, with the highest levels during the summerautumn months and the lowest during the periods with frozen soils, which probably reflects influence from vegetation, surface soil and peat, and possibly some benthic primary production in the streams. Seasonal changes in $\mathrm{SO}_{4}^{*}$ were relatively small, with slightly higher concentrations during April, decreasing May-June, and then increasing again during the autumn months. The minor dilution effect on sulfate during the spring flood, in comparison with $\mathrm{pH}, \mathrm{ANC}$ and $\mathrm{BC}^{*}$, indicates an influence from precipitation-derived sulfate from the snowpack and a possible contribution from older deposits of sulfur in the wetlands from periods with higher sulfur deposition.

The general deficit of alkalinity in the streams (Fig. 9) indicates a relatively high susceptibility to acid episodes during the high flow periods, which was also observed as sharp drops in $\mathrm{pH}$ and ANC. At unlimed conditions in the streams, the major cause of the loss of $\mathrm{ANC}$ and lowered $\mathrm{pH}$ at high flow was the dilution of $\mathrm{BC}^{*}$, decreasing with up to $0.36 \mathrm{meqL}^{-1}$ (Fig. 6). Other ions behaved slightly differently among the streams. In Djursvasslan (5004) with the largest loss of $\mathrm{BC}^{*}$, the organic anions increased slightly at high flow. This stream drains large wetlands that can release organic anions that may have contributed to the observed losses of ANC. In the other two streams, the organic anions did not change or were diluted at flow peak, such as in stream 5111, which was less influenced by wetlands. Sulfate was unchanged in stream 5004, somewhat diluted in 5006, and generally enriched in 5111, whereas changes in chloride and nitrate were minor and did not contribute to the loss of ANC in any substantial way (Fig. 6). Thus, the base cation dilution was the overall most important reason for the ANC depression at acid episodes in these streams with varying contributions from the enrichment of sulfate or organic acids.

These results are in agreement with other stream water studies in northern Sweden and in the north-eastern USA. Laudon and Bishop (1999) found that dilution of base cations and, in some cases, enrichment of organic anions were the most important causes for ANC loss at high flow episodes in five streams in northern Sweden. In another study, dilution at high flow was found to be the main cause for $58 \%$ of identified acid episodes among 87 streams in Sweden, while enrichment of sulfate was found to be the main reason for $26 \%$ of the episodes. The sulfate-related episodes were often related to preceding drought periods (Erlandsson et al., 2010). Wigington et al. (1996) found that dilution of base cations provided the most important contributions to the ANC depressions during episodes in streams in the northeastern USA, with some contributions from organic anions and sulfate. In an experimental study where ammonium sul- fate repeatedly was added to the Bear Brook Watershed in north-eastern USA, sulfate was the most important driver of the loss of ANC, and the acid episodes were mostly associated with snow melt events and showed a steady increase following the start of the treatment (Laudon and Norton, 2010).

During acid episodes, extremely high concentrations of metals, especially $\mathrm{Fe}, \mathrm{Mn}$ and $\mathrm{Al}$, occurred in the stream waters (Borg et al., 1995) and large deposits of precipitated $\mathrm{MnO}_{2}$ and $\mathrm{FeOOH}$ were formed in the streambeds further downstream (Erik Olofsson, personal communication, 1985). Earlier studies involving the speciation of metal forms using cation exchange and in situ dialysis have confirmed that there is a high portion of particulate and organically complexed $\mathrm{Fe}$ during high flow periods (Borg 1986). Similarly, less than $20 \%$ of $\mathrm{Pb}$ occurred as dissolved (dialyzable), in contrast to $\mathrm{Cd}$ (up to $75 \%$ ) and $\mathrm{Cu}(30-100 \%)$. The extreme levels and the distribution in the streams were likely mediated by the following processes: In the upper part of the catchments, there are old sediments originating from former lake basins formed by the last glaciation. These sediments consist of fine particulate silt with $\mathrm{Fe}$ and $\mathrm{Mn}$ in reduced forms bound as sulfides and carbonates. Normally, the $\mathrm{pH}$ of the groundwater flowing through these sediments is sufficiently high to prevent the release of $\mathrm{Fe}$ (II) and Mn(II). However, as acid deposition increased and the groundwater $\mathrm{pH}$ also successively decreased, colloidal and particulate forms of $\mathrm{Mn}$ and $\mathrm{Fe}$ could dissolve and be transported to surface water. Finally, when exposed to oxygenated stream water, we expect that the released metals were oxidized and eventually precipitated further downstream. Since the wetland liming operations in the catchment of river Djursvasslan and its tributaries started in 1985, no high peak values of $\mathrm{Fe}, \mathrm{Mn}$ or $\mathrm{Al}$ have been observed (Fig. 7). The application of lime on the wetlands was primarily focused on areas with groundwater discharge and apparently trapped metals successfully in the soils and peatlands.

\section{Recovery from acidification}

In a study of lakes in northern Sweden, the recovery from episodic acidification was related to the declining sulfate deposition during winter (Laudon and Bishop, 2002). Also in the streams studied here we have seen a long-term recovery from acidification in response to decreasing deposition. The most severe acid episodes have not appeared after 2004 (Fig. 3). However, since 2005 there is no clear evidence of further recovery. During 2005-2012 the unlimed streams in the study area continue to experience frequent acid episodes, with $\mathrm{pH}$-drops to 5.0 or below, with complete loss of alkalinity. Exceedance of the critical load of acidity in this region is still $200-400 \mathrm{keq} \mathrm{km}^{-2}$, after a decrease from $400-700 \mathrm{keq} \mathrm{km}^{-2}$ during the 1980s (Sverdrup et al., 2002). Despite the large decrease in the acid deposition since the 1980s, only minor recovery of the stream waters can be 
observed during recent years. In general, the sulfate concentrations in the streams have only decreased by approximately $1 \mu \mathrm{eq} \mathrm{L}-1 \mathrm{yr}^{-1}$ during the $30 \mathrm{yr}$ study period, and in the latest 10 years, the decrease appears to have reversed. In a reference stream (5111), even an increase of sulfate by approximately $1 \mu \mathrm{eq} \mathrm{L}^{-1} \mathrm{yr}^{-1}$ was measured. Simultaneously, $\mathrm{pH}$ showed a minor annual increase by 0.03 units (Table 2).

Consequently, in addition to natural causes (e.g. dilution of $\mathrm{BC}^{*}$ at high flow), the remaining exceedance of the critical load of acidity may contribute to the acid episodes that are still occurring in the streams and to the slow recovery from acidification, even in these relatively remote areas in Sweden.

Acknowledgements. E. Olofsson and E. Melin, municipality of Härjedalen, are greatly acknowledged for water sampling, planning and managing liming operations during most of the study period, and S.-E. Backman for water sampling since 2008. P. Andersson and W. Dickson (Swedish Environmental Protection Agency) are acknowledged for planning and initiating the first investigations together with Erik Olofsson. The Swedish Environmental Protection Agency, the County Administration in Jämtland (J.-E. Åslund, Östersund) and the Swedish Agency for Marine and Water Management financed the sampling and chemical analyses.

Edited by: T. J. Battin

\section{References}

Ahlström, J. and Isaksson, K. E.: Försurningsläget i Norrlands inland och fjälltrakter, Swedish Environmental Protection Agency Report 3781, 136 pp., 1990.

Ahlström, J., Degerman, E., Lindgren, G. and Lingdell, P. E.: Försurning av små vattendrag i Norrland, Statens naturvårdsverk, report 4343, 129 pp., 1995.

Almer, B., Dickson, W., Ekström, C., Hörnström, E. and Miller, U.: Effects of acidification on Swedish lakes, Ambio, 3, 29-36, 1974.

Andersson, P. and Nyberg, P.: Experiments with brown trout (Salmo trutta $L$.) during spring in mountain streams at low $\mathrm{pH}$ and elevated levels of iron, manganese and aluminium, Rep. Inst. of Freshwater Research, 61, 34-47, 1984.

Andrén, C.: Benthic fauna and diatoms in running waters within IKEU-programme, edited by: Munthe, J. and Jöborn, A., Evaluation of the IKEU-programme 1990-2006, Report 6302, Swedish Environmental Protection Agency, Stockholm, 454-472, 2009.

Andrén, C. and Rydin, E.: Which aluminium fractionation method will give true inorganic monomeric $\mathrm{Al}$ results in fresh waters (not including colloidal Al)?, J. Environ. Monit. 11, 1639-1646, 2009.

Bjärnborg, B.: Dilution and acidification effects during spring flood of four Swedish mountain brooks, Hydrobiologia, 101, 19-26, 1983.

Borg, H.: Metal speciation in acidified mountain streams in central Sweden, Water Air Soil Pollut., 30, 1007-1014, 1986.

Borg, H., Andersson, P., Nyberg, P. and Olofsson, E.: Influence of wetland liming on water chemistry of acidified mountain streams in Lofsdalen, central Sweden, Water Air Soil Pollut., 85, 907912, 1995.
CLRTAP: Convention of Long-Range Transboundary Air Pollution, ECE, UNEP, Geneva, 1979.

CLRTAP: Convention of Long-Range Transboundary Air Pollution, ECE, UNEP, Helsinki, 1985.

Dickson, W.: Properties of acidified waters, edited by: Drablös, D. and Tollan, A., Ecological impact of acid precipitation, SNSFproject, Oslo-Ås, 75-83, 1980.

Dillon, P. J., Jeffries, D. S., Scheider, W. A., and Yan N. D.: Some aspects of acidification in Southern Ontario, edited by: Drablös, D. and Tollan, A. Ecological Impact of Acid Precipitation, SNSF-project, Oslo-Ås, 212-213, 1980

Dillon, P. J., Yan, N. D., and Harvey H. H.: Acidic deposition: effects on aquatic ecosystems, CRC Cr. Rev. Anal. Chem., 13, 167-194, 1984.

Driscoll, C. T.: A procedure for the fractionation of aqueous aluminium in dilute acidic waters, Intern. J. Environ. Anal. Chem., 16, 267-283, 1984.

Edberg, F., Borg, H. and Åslund, J. E.: Episodic events in water chemistry and metals in streams in northern Sweden during spring flood, Water Air Soil Poll., 130, 1697-1702, 2001.

Environment '82 Committee: Acidification Today and Tomorrow, Stockholm conference on the acidification of the environment, Swedish Ministry of Agriculture, 1982.

Erlandsson, M., Buffam, I., Fölster, J., Laudon, H., Temnerud, J., Weyhenmeyer, G. A., and Bishop, K.: Thirty-five years of synchrony in the organic matter concentrations of Swedish rivers explained by variation in flow and sulphate, Glob. Change Biol., 14, 1191-1198, 2008.

Erlandsson, M., Laudon, H., and Fölster, J.: Spatiotemporal patterns of drivers of episodic acidification in Swedish streams and their relationships to hydrometeorological factors, Sci. Total. Environ., 408, 4633-4643, 2010

Evans, C. D., Monteith, D. T. and Cooper, D. M.: Long-term increases in surface water dissolved organic carbon: Observations, possible causes and environmental impacts, Environ. Pollut., 137, 55-71, 2005.

Evans, C. D., Chapman, P. J., Clark, J. M., Monteith, D. T., and Cresser, M. S.: Alternative explanations for rising dissolved organic carbon export from organic soils, Glob. Change Biol., 12, 2044-2053, 2006.

Freeman, C.: Export of dissolved organic carbon from peatlands under elevated carbon dioxide levels, Nature, 430, 195-198, 2004.

Helsel, D. and Hirch, R. Statistical methods in water resources, Amsterdam, Elsevier Science B. V., 1992.

Hendrey, G. R., Galloway, J. N., Norton, S. A., Schofield, C. L., Burns, D. T., and Schaffer, P. W.: Sensitivity of the eastern United States to acid precipitation impacts on surface waters, edited by: Drablös, D. and Tollan, A. Ecological impact of acid precipitation, SNSF-project, Oslo-Ås, 216-217, 1980.

Henriksen, A. : Acidification of fresh waters - a large scale titration, edited by: Drablös, D. and Tollan, A. Ecological impact of acid precipitation, SNSF-project, Oslo-Ås, 68-74, 1980.

Jacks, G., Olofsson, E., and Werme, G.: An acid surge in a wellbuffered stream, Ambio, 15, 282-285, 1986.

Jennings, E., Järvinen, M., Allot, N., Arvola, L., Moore, K., Naden, P., Aonghusa, C. N., Noges, T., and Weyhenmeyer, G. A.: The impact of the changing climate on the flux of dissolved organic carbon from catchments, edited by: George, D. G., in: The impact 
of climate change on European lakes, Aquatic Ecology Series, Springer, 199-220, 2010.

Laudon, H. and Bishop, K.: Quantifying sources of acid neutralisation capacity depression during spring flood episodes in Northern Sweden, Environ. Pollut., 105, 427-435, 1999.

Laudon, H. and Bishop, K.: The rapid and extensive recovery from episodic acidification in northern Sweden due to declines in $\mathrm{SO}_{4}^{2-}$ deposition, Geophys. Res. Lett., 29, 351-354, 2002.

Laudon, H. and Norton, S. A.: Drivers and evolution of episodic acidification at the Bear Brook Watershed in Maine, USA, Environ. Monit. Assess., 171, 59-69, 2010.

Moldan, F., Cosby, B. J., Wright, R. F., and Stadmark, J.: MAGIC library for Swedish lakes: evaluation of multiple calibrations, IVLreport B2104, Swedish Environmental Research Institute Ltd, Stockholm, 2013.

Monteith, D. T., Stoddard, J. L., Evans, C. D., de Wit, H. A., Forsius, M., Högåsen, T., Wilander, A., Skjelkvåle, B. L., Jeffries, D. S., Vuorenmaa, J., Keller, B., Kopacek, J., and Vesely, J.: Dissolved organic carbon trends resulting from changes in atmospheric deposition chemistry, Nature, 450, 537-540, 2007.

Mörth, C. M., Laudon, H., Mellqvist, E., Torssander, P., and Giesler, R.: Sources of stream water sulphate during the spring snowmelt in boreal streams: Evidence from $\delta^{34} \mathrm{~S}$ isotope measurements, J. Geophys. Res., 113, G01005, doi:10.1029/2007JG000457, 2008.

Nyberg, P., Andersson, P., Degerman, E., Borg, H., and Olofsson, E.: Labile inorganic manganese - an overlooked reason for fish mortality in acidified streams?, Water Air Soil Poll., 85, 333340, 1995

Odén, S.: The acidification of air and precipitation and its consequences on the natural environment, Swed. Nat. Sci. Res. Council, Ecol. Comm. Bull., 1, 1-68, 1968.

Skjelkvåle, B. L., Borg, H., Hindar, A., and Wilander, A.: Large scale patterns of chemical recovery in lakes in Norway and Sweden: Importance of seasalt episodes and changes in dissolved organic carbon, Appl. Geochem., 22, 1174-1180, 2007.

Stoddard, J. L., Jeffries, D. S., Lükewille, A., Clair, T. A., Dillon, P. J., Driscoll, C. T., Forsius, M., Johannessen, M., Kahl, J. S., Kellogg, J. H., Kemp, A., Mannio, J., Monteith, D. T., Murdoch, P. S., Patrick, S., Rebsdorf, A., Skjelkvåle, B. L., Stainton, M. P., Traaen, T., van Dam, H., Webster, K. E., and Wilander, A.: Regional trends in aquatic recovery from acidification in North America and Europe, Nature, 401, 575-578, 1999.
Sverdrup, H., Staaf, H., and Rapp, L. A. M.: Kritisk belastning för svavel och kväve, edited by: Bertills, U. and Lövblad, G., Kritisk belastning för svavel och kväve, Swedish Environmental Protection Agency, 52-80, 2002.

Swedish Environmental Protection Agency: Acidification and liming of Swedish freshwaters, Monitor, 12, 144 pp., 1991.

UNECE: The 1985 Helsinki Protocol on the Reduction of Sulphur Emissions or their Transboundary Fluxes by at least 30 per cent, Protocol to the 1979 convention on long-range transboundary air pollution on further reduction of sulphur emissions, Helsinki, 1987.

UNEP: Declaration of the United Nations Conference of the Human Environment, 1972, United Nations Environment Programme, 21st plenary meeting, 1972-06-16, Stockholm, 1972.

Wern, L. and Bärring, L.: Sveriges vindklimat 1901-2008 - Analys av förändring i geostrofisk vind, Meteorologi Nr 138/2009, Swedish Meteorological and Hydrological Institute, 2009.

Weyhenmeyer, G. A. and Karlsson, J.: Nonlinear response of dissolved organic carbon concentrations in boreal lakes to increasing temperatures, Limnol. Oceanogr., 54, 2513-2519, 2009.

Wigington, P. J., DeWalle, D. R., Murdoch, P. S., Kretser, W. A., Simonin, H. A., VanSickle, J., and Baker, J. P.: Episodic acidification of small streams in the northeastern United States: Ionic controls of episodes, Ecol. Appl., 6, 389-407, 1996.

Wilander, A. and Lundin, L.: Recovery of surface waters and forest soils in Sweden, edited by: Warfvinge, P. and Bertills, U. Recovery from acidification in the natural environment: Present knowledge and future scenarios, Swedish Environmental Protection Agency, Report 5034, 53-64, 2000.

Wilander, A.: Effects of reduced S deposition on large-scale transport of sulphur in Swedish rivers, Water Air Soil Poll., 130, 1421-1426, 2001.

Winterdahl, M., Temnerud, J., Futter, M. N., Löfgren, S., Moldan, F., and Bishop, K.: Riparian zone influence on stream water dissolved organic carbon concentrations at the Swedish integrated monitoring sites, Ambio, 40, 920-930, 2011.

Wright, R. F., Harriman, R., Henriksen, A., Morrison, B., and Caines, L. A.: Acid lakes and streams in the Galloway area, southwestern Scotland, edited by: Drablös, D. and Tollan, A. Ecological impact of acid precipitation, SNSF-project, Oslo-Ås, 248-249, 1980. 